\title{
EVALUATION OF WILD SPECIES OF LENTIL FOR AGRO-MORPHOLOGICAL TRAITS
}

\author{
Aditya Pratap*, Jitendra Kumar and Shiv Kumar ${ }^{1}$ \\ Crop Improvement Division, \\ Indian Institute of Pulses Research, Kanpur-208 024, India
}

Received: 29-08-2013

Accepted: $15-10-2013$

\section{ABSTRACT}

Most of the existing varieties of lentil (Lens culinaris ssp. culinaris) have been developed mainly through intraspecific hybridization and pureline selection leading to a narrow genetic base in cultivated populations. This makes them vulnerable to a number of biotic and abiotic stresses besides reducing their genetic potential due to lesser hidden variability. Distant hybridization involving wild accessions increases genetic variability and also helps in introgression of desirable genes rendering cultivated species more usable. Keeping this in view, wild accessions of lentil procured from ICARDA, Aleppo, Syria were established and evaluated under local conditions at IIPR, Kanpur. These comprised 88 accessions from Lens nigricans, $L$. culinaris ssp. odemensis, $L$. culinaris ssp. orientalis, $L$. culinaris ssp. tomentosus, $L$. ervoides, $L$. lamotteiand unknown Lens spp. The results showed significant genetic variation among the wild accessions for all characters except cotyledon colour. PCA analysis of the morphological data resulted in clustering of $\mathbf{8 8}$ wild accessions into three groups and distinct position of each genotype was observed within each group. The first three most informative components in PCA analysis individually accounted for $89.35,4.38$ and $2.3 \%$ of total variation, respectively and collectively these explained about $95 \%$ of the total variability. While more traits and multilocation data need to be considered for getting more reliable results, in general $L$. envoides was observed to possess useful traits like plant height, internode length and pods/cluster and therefore could be utilized for genetic improvement of cultivated lentil.

Key words: Distant hybridization, Lentil, L. ervoides, PCA, Wild accessions.

\section{INTRODUCTION}

Lentil (Lens culinaris Medikus ssp. culinaris) is an important cool-season food legume and ranksfifth in production in the world after dry beans, chickpea, cowpea and peas. In 2012, global lentil production was about 4.55 million tonnes from an estimated 4.25 million ha area with an average yield of $1070 \mathrm{~kg}$ per ha (FAO, 2013). Canada is the largest producer of lentil followed by India, Australia_and Turkey. During 2011-12, India harvested 0.95 million ton lentils from 1.60 million ha area with an average yield of $594 \mathrm{~kg}$ per ha. Evidently, the present productivity of lentil in India is very low in spite of a large number of improved varieties developed for cultivation in different agroecological zones of the country. Earlier studies have confirmed that these varieties, mostly developed through intraspecific hybridization and pure line selection, have narrow genetic base (Kumar et al. 2004). This makes them vulnerable to several biotic and abiotic stresses besides limiting their realizable yield potential. Introgression of useful genes from wild relatives has been suggested to overcome the problem of narrow genetic base of lentil (E rskine et al., 1998; Rahman et al., 2009). This may help in introgresson of desirable genes or gene combinations into the cultivated backgrounds, thereby rendering them more usable (Pratap et al., 2009; Kumar et al., 2014).

It is well known that wild species are a rich reservoir of useful alien genes, which are no longer available within the cultivated gene pool (Tanksley and McCouch, 1997). Therefore, continuous efforts have been made to collect and conserve wild relatives

*Corresponding author's e-mail: adityapratapgarg@gmail.com

IInternational Centre for A gricultural Research in the Dry A reas, Rabat Office, P.O. B ox 6299, Rabat - instituts, Rabat, Morocco 
of various food legume crops including lentil in the national and international gene banks. ICARDA global collection of Lens has about 587 wild accessions representing six Lens species and subspecies from 26 countries (Kumar et al., 2011). Efforts have also been made to search for genes imparting resistance to biotic and abiotic stresses and other traits among the wild relatives and success of introgression of alien genes from wild relatives has been achieved for few diseases and insect-pests which are controlled by major gene(s) (Ladizinsky et al., 1988, Hajjar and Hodgkin 2007; Fiala et al., 2009; Tullu et al., 2011). Significant advances have recently been made both in the molecular technologies and hybridization procedures that make it possible to transfer alien gene(s) into the cultivated germplasm. However, the use of wild relatives for lentil improvement has remained limited, and that too confined to only a few wild accessions, mainly due to limited access to wild species, difficulties in their establishment, non-synchrony in flowering between cultivated and wild species and various preand post-fertilization barriers (Kumar et al., 2011). Further, most of the wild germplasm collection has largely remained unevaluated for morphophysiological traits under Indian soil and climatic conditions. Keeping this in view, this study was conducted to establish exotic wild accessions of lentil under controlled conditions at IIPR, Kanpur and evaluate them to identify most promising donors for various yield and yield contributing traits.

\section{MATERIALS AND METHODS}

Eighty eight wild accessions of lentil representing six Lens species and sub-species were procured from the International Center for Agricultural Research in the Dry Areas (ICARDA), Aleppo, Syria under standard material transfer agreement during 2008 (Tables 1 and 2). The seeds of these accessions were evaluated in pots at the main research farm of Indian Institute of Pulses Research, Kanpur during 2009-10 and 2010-11. The 12-inch diameter plastic pots were filled with the sterilized mixture of sand, farm yard manure and soil (1: 1:2). Before sowing, seeds were scarified to overcome the germination problem due to hard seed coat in wild accessions. For seed coat scarification, 10 seeds of each accession were held with the thumb and an excision was made on the reverse side of the seed using a sharp surgical blade. Immediate after the scarification, seeds were incubated on moist filter paper at room temperature for 24 hours in Petriplates, followed by their direct sowing in the pots. Germination was observed in all the accessions within 6-7 days though only 88 accessions reached the maturity stage. Twelve accessions were lost during the crop development owing to various reasons, the most prominent being very poor initial seedling vigour and consequently drying of plants. Nevertheless, the germination percentage differed within the accessions also and it ranged $40-100 \%$ in different wild accessions. Observations on 88 accessions which reached maturity were recorded for 11 morphological traits. Plant height, internode length, rachis length, leaf length, leaf width, pods/ cluster and seeds/pod were recorded on four plants per accession while data on presence or absence of tendrils were recorded on three random plants. Data on 100-seed weight and cotyledon colour were taken after the harvest and threshing. All the characters were recorded when these had full expression.

The data of both the years were pooled to work out range and mean. The pooled data were subjected to similarity co-efficient analysis ( accard 1908) based on which a dendrogram was constructed using unweighted pair group method with arithmetic average (UPG MA) using NTSYS pc$2.11 x$ (Rolf, 1998) software. The data were also subjected to Principal Component Analysis (PCA) using the same software.

\section{RESULTS AND DISCUSSION}

Lens gene-pool consists of many wild relatives offering resistance to biotic (Ahmad et al., 1997) and abiotic stresses (Hamdi et al., 1996). Accessions belonging to $\mathrm{L}$. odemensis and $\mathrm{L}$. ervoides showed drought tolerance (Hamdi and

TABLE 1: Wild accessions of lentil used in the present study.

\begin{tabular}{lc}
\hline Name of the species & No. of accessions \\
\hline Lens nigricans & 16 \\
L. culinaris ssp. odemensis & 10 \\
L. culinaris ssp. orientalis & 22 \\
L. culinaris ssp. tomentosus & 06 \\
L. ervoides & 31 \\
L. lamottei & 02 \\
Lens spp. & 01 \\
Total & 88 \\
\hline
\end{tabular}


Vol. 37, No. 1, 2014

TABLE 2: Wild accessions of lentil evaluated in present study with their country of origin and cotyledon colour.

\begin{tabular}{|c|c|c|c|}
\hline Name of the genotype & ILWL & Country of origin & Cotyledon colour \\
\hline L. culinaris ssp. orientalis & 7 & Turkey & Red \\
\hline Lens spp. & 9 & Syria & Red \\
\hline L. culinaris ssp. tomentosus & 11 & Syria & Red \\
\hline Lens nigricans & 13 & Italy & Red \\
\hline L. lamottei & 14 & France & Red \\
\hline Lens nigricans & 15 & France & Red \\
\hline Lens nigricans & 16 & France & Red \\
\hline Lens nigricans & 18 & France & Red \\
\hline Lens nigricans & 19 & Spain & Yellow \\
\hline L. culinaris ssp. odemensis & 20 & Palestine & Red \\
\hline L. culinaris ssp. odemensis & 21 & Palestine & Yellow \\
\hline Lens nigricans & 22 & Italy & Yellow \\
\hline Lens nigricans & 23 & Italy & Red \\
\hline Lens nigricans & 26 & Croatia & Red \\
\hline Lens nigricans & 28 & $\mathrm{BIH}$ & Red \\
\hline L. lamottei & 29 & Spain & Red \\
\hline Lens nigricans & 30 & Spain & Red \\
\hline Lens nigricans & 31 & Spain & Red \\
\hline Lens nigricans & 32 & Spain & Red \\
\hline Lens nigricans & 33 & Spain & Red \\
\hline L. culinaris ssp. odemensis & 35 & Turkey & Red \\
\hline L. culinaris ssp. odemensis & 36 & Turkey & Red \\
\hline Lens nigricans & 37 & Turkey & Red \\
\hline L. culinaris ssp. odemensis & 39 & Turkey & Yellow \\
\hline L. ervoides & 40 & Ukraine & Red \\
\hline L. ervoides & 41 & Turkey & Red \\
\hline L. ervoides & 42 & Italy & Red \\
\hline L. ervoides & 45 & Croatia & Red \\
\hline L. ervoides & 48 & Croatia & Red \\
\hline L. ervoides & 49 & Croatia & Red \\
\hline L. ervoides & 52 & Croatia & Red \\
\hline L. ervoides & 55 & Palestine & Red \\
\hline L. ervoides & 56 & Palestine & Red \\
\hline L. ervoides & 57 & Palestine & Red \\
\hline L. ervoides & 58 & Turkey & Red \\
\hline L. ervoides & 59 & Turkey & Red \\
\hline L. ervoides & 60 & Turkey & Red \\
\hline L. ervoides & 62 & Turkey & Red \\
\hline L. ervoides & 65 & Turkey & Red \\
\hline L. ervoides & 67 & Turkey & Red \\
\hline L. culinaris ssp. orientalis & 69 & Uzbekistan & Red \\
\hline L. culinaris ssp. orientalis & 78 & Iran & Red \\
\hline L. culinaris ssp. orientalis & 82 & Iran & Red \\
\hline L. culinaris ssp. odemensis & 83 & Turkey & Red \\
\hline L. culinaris ssp. orientalis & 85 & Turkey & Red \\
\hline L. culinaris ssp. orientalis & 87 & Turkey & Red \\
\hline L. culinaris ssp. orientalis & 96 & Turkey & Red \\
\hline L. culinaris ssp. orientalis & 97 & Turkey & Red \\
\hline L. culinaris ssp. orientalis & 103 & Turkey & Red \\
\hline L. culinaris ssp. orientalis & 104 & Turkey & Red \\
\hline L. culinaris ssp. orientalis & 105 & Turkey & Red \\
\hline L. culinaris ssp. orientalis & 109 & Turkey & Red \\
\hline L. nigricans & 111 & Turkey & Red \\
\hline L. nigricans & 112 & Turkey & Red \\
\hline L. culinaris ssp. orientalis & 122 & Syria & Red \\
\hline L. culinaris ssp. orientalis & 124 & Syria & Red \\
\hline
\end{tabular}


L. ervoides

L. ervoides

L. ervoides

L. ervoides

L. ervoides

L. ervoides

L. ervoides

L. ervoides

L. ervoides

L. culinaris ssp. orientalis

L. culinaris ssp. orientalis

L. ervoides

L. ervoides

L. ervoides

L. culinaris ssp. odemensis

L. culinaris ssp. odemensis

L. culinaris ssp. odemensis

L. culinaris ssp. odemensis

L. culinaris ssp. orientalis

L. culinaris ssp. orientalis

L. culinaris ssp. orientalis

L. ervoides

L. ervoides

L. ervoides

L. culinaris ssp. orientalis

L. culinaris ssp. orientalis

L. culinaris ssp. tomentosus

L. culinaris ssp. tomentosus

L. culinaris ssp. tomentosus

L. culinaris ssp. tomentosus

L. culinaris ssp. tomentosus

L. culinaris ssp. orientalis

128
129
130
131
132
133
135
140
142
143
152
155
159
162
164
167
173
175
176
181
183
184
186
187
189
192
194
195
196
198
199
200
19

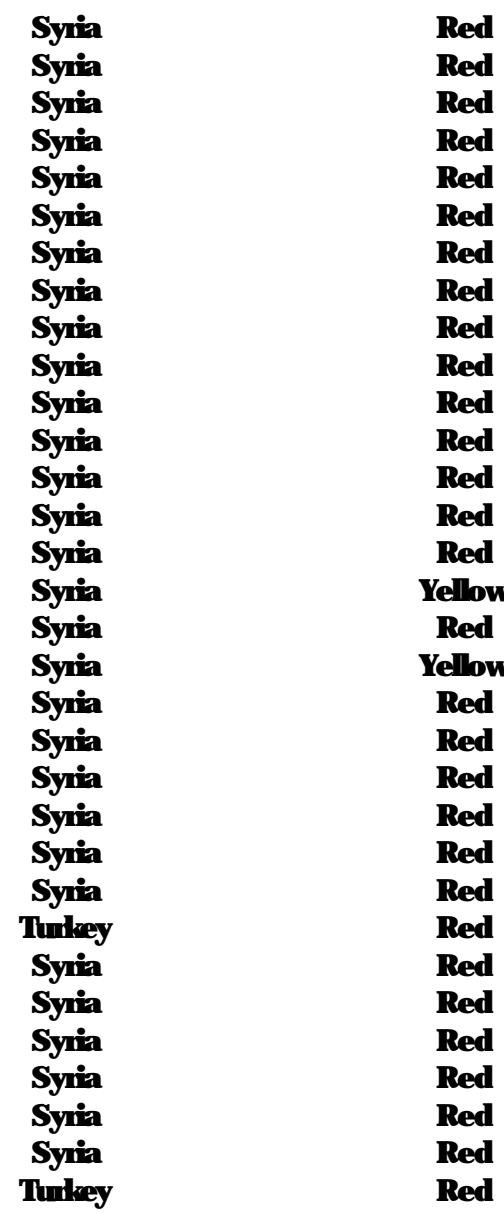

Erskine, 1996; G upta and Sharma, 2006), while cold tolerance and earliness have been observed in $\mathrm{L}$. culinaris ssp. orientalis (Hamdi et al., 1996). Combined resistance to ascochyta blight and fusarium wilt (ILWL 138) or anthracnose diseases (IG 72653, IG 72646, IG 72651) have also been identified (Bayya et al., 1995, Tullu et al., 2006). Earlier, a few attempts have been made at ICARDA, Aleppo, Syria to evaluate wild Lens taxa for agromorphological traits besides key biotic and abiotic stresses (Erskine and Saxena, 1993; Bayya et al., 1995; Hamdi and erskine, 1996; Ferguson and Robertson, 1999; Tullu etal. 2006). However, in the Indian context such evaluation has not been done earlier to identify useful donors for the local conditions. To address this and to identify suitable wild accessions which could be used as potential donors, this study was conducted on 88 accessions of lentil representing all the six wild Lens species and sub-species. Though initial seedling vigour was less in wild species as compared to the cultivated check, the wild accessions developed profusely later on and yielded good biomass (Fig. 1). The results showed significant genetic variation among the wild accessions for all characters except cotyledon colour (Tables 2 and 3). A wide range of variability has been reported earlier also by Gupta and Sharma (2006) for yield attributes and biotic and abiotic stresses among 70 accessions of four wild species/ subspecies (L. culinaris ssp. orientalis, L. odemensis, $L$. ervoides and $L$. nigricans). The results of principal component analysis are presented in Figure 2 and mean and range are presented in Table 3. On the basis of 100-seed weight, cultivated lentil germplasm is classified into small $(<2 \mathrm{~g})$, medium $(2-2.5 \mathrm{~g})$, large (2.6-3.0 g) and very large (>3 g) seed size groups (Dixit et al. 2011). Following this scale, it was observed that all the wild accessions under evaluation belonged to the small seed size category. The seed size ranged between 0.3 and $1.34 \mathrm{~g} / 100-$ seeds in different accessions, the highest in L. culinaris ssp. tomentosus (ILWL 199). Though wild accessions cannot be ideal targets for improving seed size as sufficient variability for seed size exits in the 
Vol. 37, No. 1, 2014

TABLE 3: Morpho-physiological variation in wild accessions of lentil

\begin{tabular}{|c|c|c|c|c|}
\hline Trait & Mean & Range & Minimum & Maximum \\
\hline Plant height (cm) & 24.15 & $11.33-33.33$ & $\begin{array}{l}\text { L. culinaris ssp. orientalis } \\
\text { (IL WL 143) }\end{array}$ & L. ervoides (ILWL130) \\
\hline $\begin{array}{l}\text { Interno de length } \\
(\mathrm{cm})\end{array}$ & 2.37 & $0.5-4.3$ & $\begin{array}{l}\text { L. culinaris Ssp. orientalis } \\
(\text { ILWL 124) }\end{array}$ & L. ervoides (ILWL 140) \\
\hline Primary branches & 3.71 & $1-7$ & L. ervoides (ILWL 142) & $\begin{array}{l}\text { L. culinaris ssp. tomentosus } \\
\text { (ILWL 195) }\end{array}$ \\
\hline Rachis length & 1.37 & $0.5-5.0$ & $\begin{array}{l}\text { L. culinaris ssp. orientalis } \\
\text { (ILWL 87) }\end{array}$ & L. nigricans (ILW L173) \\
\hline Pods/d uster & 1.35 & $1-3$ & $\begin{array}{c}\text { Most of the accessions (58 } \\
\text { accessions) }\end{array}$ & L. ervoides (ILWL 56) \\
\hline Leaf length $(\mathrm{cm})$ & 0.74 & $0.2-1.5$ & $\begin{array}{l}\text { L. culinaris ssp. orientalis } \\
\text { (IL WL124) }\end{array}$ & $\begin{array}{l}\text { L. ervoides (ILW L131), L. culinaris } \\
\text { ssp. oriental is (ILW L 200), L. } \\
\text { nigricans (ILWL32) }\end{array}$ \\
\hline Leaf width (cm) & 0.26 & $0.1-0.6$ & $\begin{array}{l}\text { L. culinaris ssp. odemensis } \\
\text { (ILW L 167, ILWL 175), L. } \\
\text { culinaris ssp. tomentosus } \\
\text { (ILWL 196), L. ervoides } \\
\text { (ILWL 65) }\end{array}$ & $\begin{array}{l}\text { L. culinaris ssp. orientalis } \\
\text { (IL WL 78) }\end{array}$ \\
\hline Seeds/pod & 1.66 & $1-3$ & 30 accessio ns & L. nigricans (IL WL 28) \\
\hline 100 -seed weight & 0.74 & $0.32-1.34$ & $\begin{array}{l}\text { L. ervoides (ILWL 132, } \\
\text { ILW L135) }\end{array}$ & $\begin{array}{l}\text { L. culinaris ssp. tomentosus } \\
\text { (ILWL 199) }\end{array}$ \\
\hline
\end{tabular}

primary gene-pool itself, involving wild species in lentil hybridization programmes can help to generate the transgressive sergeants for this trait. A very good amount of variability was observed for plant height which ranged between 11.33 and $33.33 \mathrm{~cm}$, the highest being in L. ervoides (ILWL 130) and minimum in L. culinaris ssp. orientalis (ILWL 143).

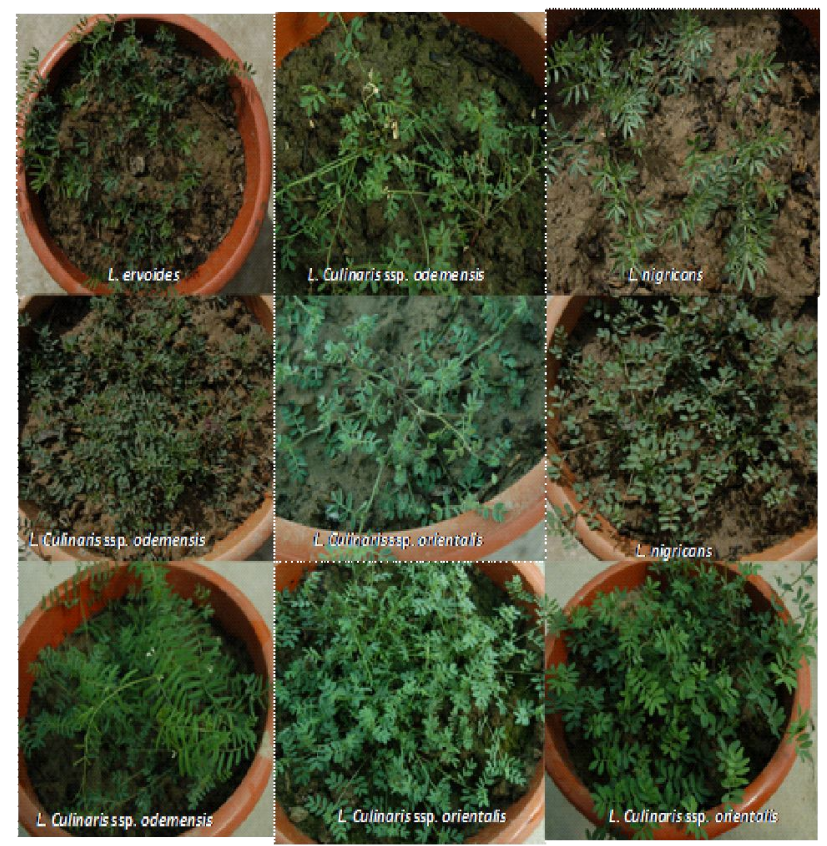

FIG. 1: Morpho-physiological variation in wild accessions of lentil
The internode length ranged between 0.5 and 4.3 $\mathrm{cm}$, the maximum being in L. ervoides (ILWL 140) and the minimum in L. culinaris ssp. orientalis (ILWL 124). It is noticeable that both plant height as well as internode length were maximum in L. ervoides and minimum in L. culinaris ssp. orientalis although their accession numbers were different. This suggests that $L$. ervoides in general has a tendency of taller plants with longer internodes. Singh and Singh (1991) and Pandey et al. (1992) indicated that plant height, number of pods/plant and seeds/pod had significant and positive correlations with yield/plant in both, macrosperma and microsperma types.

The primary branches/plant varied between 1-7, the highest number of primary branches being in L. culinaris ssp. tomentosus (ILWL 195) and the minimum in L. culinaris ssp. orientalis (ILWL 87). Since the cultivated lentil has 3-4 primary branches/ plant, L. culinaris ssp. tomentosus can be utilized for increasing this trait in the cultivated lentil. Pandey et al., (1992) and Esmail et al. (1994) reported that secondary branches/plant contribute directly to seed yield. Pods/cluster ranged between 1-3. Therefore, increasing branches/plant may be an ideal target for increasing seed yield/plant using wild lentil. While most of the accessions (58) recorded only 1 pod/ cluster, only one accession of L. ervoides (ILWL 56) recorded 3 pods/cluster. Though 3 pods/clusters can 


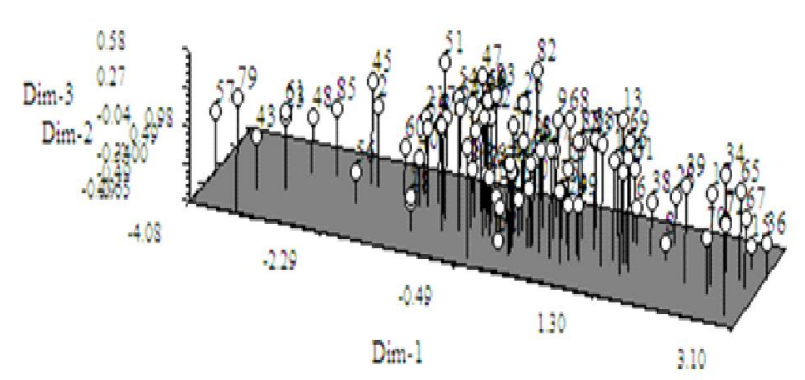

FIG. 2: PCA analysis of the 88 wild accessions of lentil based on phenotypic data

be observed in the germplasm of cultivated genepool, every cluster of a plant does not have same number of pods. Therefore, this trait can play an important role in increasing seed yield if this trait expresses uniformly within plant. There was considerable variability for leaf length and leaf width also. While leaf length ranged between $0.2-1.5 \mathrm{~cm}$, the average being $0.74 \mathrm{~cm}$, leaf width varied between 0.41-0.6 cm.

Seeds/pod is an important criterion for selection as it directly contributes to seed yield and stability in lentil. While most of the accessions recorded one seed per pod, only one accession of $L$. nigricans (ILWL 28) recorded 3seeds/pod. Among the 88 wild accessions, 34 did nothave tendrils while the rest of the entries had medium to large tendrils thereby having a twining habit. Similarly, for cotyledon colour, it was observed that only six accessions had yellow cotyledon colour while the other had red colour. Noticeably, red cotyledon colour is preferred for consumption in South Asia and therefore, it can be preferred in lentil breeding program.

PCA analysis of the morphological data resulted in clustering of 88 wild accessions into three groups (Table 4). Distinct position of each genotype

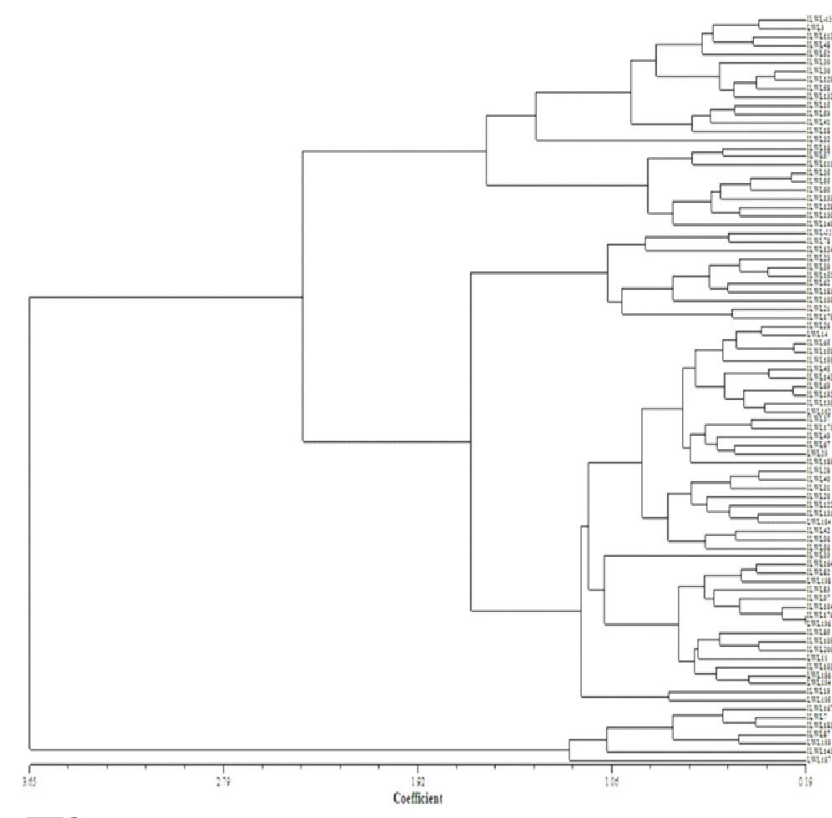

FIG 3: Dendogram based on J accard's similarity coefficient using UPGMA method of clustering

was observed within each group (Fig. 3). In the first group, there were 10 accessions, 7 being of $\mathrm{L}$. culinaris ssp. orientalis, while in the third group there were 12 accessions out of which 8 were of $L$. ervoides. Remaining 66 accessions were clustered in the II group. In earlier reports, L. culinaris ssp. orientalis, L. culinaris ssp. odemensis and $L$. nigricans ssp. odemensis have been grouped in the primary gene-pool while L. ervoides and L. nigricans fall in secondary and L. lamottei and L. culinaris ssp. tomemtosus in the tertiary gene-pool (Muehlbauer and McPhee, 2005). The first three most informative components in PCA analysis individually accounted $89.35,4.38$ and $2.3 \%$ of total variation, respectively and collectively these three components explained about $95 \%$ of the total

TABLE 4: Grouping of wild lentil accessions on the basis of UPGMA analysis.

\begin{tabular}{ccc}
\hline Cluster & $\begin{array}{c}\text { No. of } \\
\text { accessions }\end{array}$ & Name of accessions \\
\hline 1 & 10 & L. nigricans (IL WL 22), L. culinaris ssp. ori entalis (ILWL 7, 78, 87, 124, 143, 189, 192), L. \\
ervoides (ILWL 187) and L. culinaris ssp. tomentosus (ILWL 199)
\end{tabular}


variability. Therefore, more accessions as well as more parameters need to be taken into consideration to represent true genetic variability in wild accessions of lentil. In general L. ervoides was observed to possess useful traits like, plant height, internode length and pods/cluster and therefore could be utilized for genetic improvement of cultivated lentil.

\section{REFERENCES}

Ahmad, M., McN eil, D. L. and Sedcole, J . R. (1997) Phylogenetic relationships in Lens species and their interspecific hybrids as measured by morphological characters. Euphytica 94: 101-111.

Bayaa, B., Erskine, W. and Hamdi, A. (1995) Evaluation of a wild lentil collection for resistance to vascular wilt. Genet. Resour. Crop Evol. 42: 231-235.

Dixit, G.P., Katiyar, P.K. and Singh, B.B. (2011) Characterization of lentil (Lens culinaris Medik.) varieties based on morphological traits. J. Food Legumes 24: 194-197.

Erskine, W. and Saxena, M.C. (1993) Problems and prospects of stress resistance breeding in lentil. Breeding for Stress Tolerance in Cool Season Food Legumes. pp. 51-62. In: Singh K B and Saxena M C . (eds.) ICARDA/Wiley, Chichester, UK.

Erskine, W., Chandra, S., Chaudhary, M., Malik, I.A., Sarker, A., Sharma, B., Tufail, M. and Tyagi, M.C. (1998). A bottleneck in lentil: widening its genetic base in South Asia. Euphytica 101: 207-211.

Esmail, A.M., Mohamed, A.A., Hamdi, A.and Rabie, E.M. (1994). Analysis of yield variation in lentil (Lens culinaris Medik). Ann. Agric. Sci. Moshtohor. 32: 1073-1087.

FAO (2013) FAOSTAT. Available athttp://faostat.fao.org/site/567/DesktopDefault.aspx?PagelD=567\#ancor (last accessed on October 11, 2013)

Ferguson, M.E. and Robertson, L.D. (1999) Morphological and phenological variation in the wild relatives of lentil. Genet. Resour. Crop Evol. 46: 3-12.

Fiala, J V., Tullu, A., Banniza, S., Séguin-Swartz, G. and Vandenberg, A. (2009) Interspecies transfer of resistance to anthracnose in lentil Lens culinaris Medic. Crop Sci. 49: 825-8305.

Gupta, D., and Sharma, S. K. (2006) Evaluation of wild Lens taxa for agro-morphological traits, fungal diseases and moisture stress in northwestern Indian hills. Genet. Resour. Crop Evol. 53:1233-1241.

Hajjar, R., and Hodgkin, T. (2007) The use of wild relatives in crop improvement, A survey of developments over the last 20 years. Euphytica 156:1-13.

Hamdi, A. and Erskine, W. (1996) Reaction of wild species of the genus Lens to drought. Euphytica 91: 173-179.

Hamdi, A., Kusmenoglu, I. and Erskine, W. (1996) Sources of winter hardiness in wild lentil. Gen. Res. Crop Evol. 43:63-67.

J accard, P. (1908) N ouvelles recherches sur la distribution florale. Bul. Soc. Vaudoise Sci. Nat. 44: 223-270.

Kumar, J., Pratap, A., Solanki, R.K., Chaturvedi, S.K., Kumar, S. and Nadarajan N. (2012) Genomic Resources for Improving Food Legume crops. J. Agric. Sci. 150: 289-318.

Kumar, S., Gupta, S., Chandra, S. and Singh, B.B. (2004) How wide is the genetic base of pulse crops? Pulses in New Perspective. pp. 211-221.In: Ali M, Singh BB, Kumar S and Dhar V (eds.). Indian Society of Pulses Research and Development, Indian Institute of Pulses Research, Kanpur, India.

Kumar, S., Mohammad, I., Gupta, S. and Pratap, A. (2011) Distant Hybridization and alien gene introgression. Biology and Breeding of Food Legumes. pp.: 81-110. In: Aditya Pratap and J itendra Kumar (eds.) CABI, Oxfordshire, UK.

Ladizinsky, G., Pickersgill, B. and Yamamoto, K. (1988) Exploitation of wild relatives of the food legumes. In World Crops, Cool Season Food Legumes, ed. R. J. Summerfield, pp. 967-987. Dordrecht, The Netherland: Kluwer Academic Publishers.

Muehlbauer, F.J . and McPhee, K.E. (2005) Lentil (lens culinaris M edik). Genetic Resources, Chromosome Engineering and Crop Improvement, Grain Legumes. pp 219-230.In: Singh, R.J . and J auhar, P.P. (eds) Taylor \& Francis, Boca Raton, USA.

Pandey, A., Singh, D.P. and Singh, B.B. (1992) Interrelationship of yield and yield components in lentil (Lens culinaris Medik) germplasm. Indian. J. Pulses Res. 5: 142-144.

Pratap, A., Kumar, J., Solanki, R.K., Singh, I.P. and Chaturvedi, S.K. (2009). Evaluation of wild accessions of lentil for qualitative and quantitative traits. Proceedings of National Symposium on Achieving millennium development goals: Problems and Prospects. pp. 126-127. October 25-26, 2009, Bundelkhand University, J hansi (UP). 
Rahman, M.M., Sarker, A., Kumar, S., Ali, A., Yadav, N.K., and Rahman, L. (2009) Breeding for short season environments. The lentil: Botany, production and uses. p. 121-136. In: Erskine W, Muehlbauer F, Sarker A, and Sharma B (ed.) CAB Int., Wallingford, UK.

Rolf, F.J . (1998) NTSys-pc: Numerical Taxonomy and Multivariate Analysis System. Version 2.02, New York, Ererter Software.

Singh, D.P. and Singh, B.B. (1991) Evaluation of exotic germplasm in lentil. Narendra Dev J. Agric. Res. 6: 304-306. Tanksley, S.D. and McCouch, S.R. (1997) Seed banks and Molecular maps, unlocking genetic potential from the wild. Science 277: 1063-1066.

Tullu, A., Banniza, S., Bett K., and Vandenberg A. (2011) A walk on the wild side: Exploiting wild species for improving cultivated lentil. Grain Legumes 56:13-14.

Tullu, A., Buchwaldt, L., Lulsdorf, M., Banniza, S., Barlow, B., Slinkard, A.E., Sarker, A., Tar'an, T.D., Warkentin, T.D. and Vandenberg, A. (2006) Sources of resistance to anthracnose (Colletotrichum truncatum) in wild Lens species. Genet. Resour. Crop Evol. 53: 111-119. 